\title{
E-Commerce Retail Customers Repurchase Factors Influencing Identification
}

\author{
Terēze Pekša \\ Institute of Business Engineering and Management, \\ Faculty of Engineering Economics and Management, \\ Riga Technical University \\ Riga, Latvia \\ Tereze.Peksa@edu.rtu.lv
}

\begin{abstract}
With the fast-paced technological development era and the importance of using the Internet in our daily lives, e-commerce as shopping no longer seems new or unusual. Regardless of type or size, companies are using ecommerce advantage to compete in the market. Each of these companies needs a circle of independent and loyal customers. When the customer is satisfied, he gives positive feedback about the company and makes a repeat purchase. In this way, he attracts new customers to the company and provides an independent income for the company. Certain factors influence the customer's attitude and behavior. It is essential to determine what influences their customers' choices when competing to earn profit in the market; the customer must be satisfied in order for him to want to make a repurchase. Repurchases from customers indicate a loyalty to the company. Customer loyalty can be the result of a company consistently meeting and exceeding its customer expectations. Customer loyalty can have a significant impact on business growth. To assess and identify the factors influencing customer satisfaction, they are identified and offered a conceptual reflection of the current situation and offer a conceptual model of Identification Causes and Effects of Customer Satisfaction Framework (IceCSF) in e-commerce retail.
\end{abstract}

Keywords - e-commerce, unsatisfied consumer identification, consumer behavior identification, repeat purchase identification.

\section{INTRODUCTION}

At the beginning of 2020, 99.9\% of enterprises in Latvia used the Internet, and $62.6 \%$ of them had their website, including $94.1 \%$ of large enterprises, $81 \%$ of medium-sized enterprises, and 58.4\% of small enterprises, according to the annual survey of the Central Statistical Bureau on the use of information and communication technologies (ICT) and e-commerce in enterprises [1].

\author{
Jānis Pekša \\ Institute of Information Technology, \\ Faculty of Computer Science and Information Technology, \\ Riga Technical University \\ Riga, Latvia \\ Janis.Peksa@rtu.lv
}

Seeing the importance of e-commerce in our daily lives today. A returning customer is a customer who has made the first purchase and has returned to do so again. Increasing the company's profitability begins with creating its regular customer base; they are significant customers. Customers who make repeat purchases are loyal; it is also a powerful tool for attracting new customers. Loyal customers increase the company's profit because they buy more often than those who have made only one purchase. Besides, attracting a new customer to a company can cost five times more than retaining an existing customer. By increasing the number of regular customers by $5 \%$, its profit could increase from $25 \%$ to $95 \%$. It is crucial to identify the factors that encourage customers to make repeated purchases and become loyal to the company, but it is equally important to identify the factors that cause customer dissatisfaction[2].

To look for answers that affect customers repurchase factors influencing identification in e-commerce retail. The method of systematic analysis of scientific articles is used in work. By marking the current situation, identify possible challenges and propose a conceptual model that would identify the influencing factors that indicate the customer's repeated purchase. The following research question (RQ) is raised:

\section{RQ1: What factors affect a repurchase?}

The goal is to identify the factors that affect customer repurchase in e-commerce retail. After identification, offer a unifying conceptual model that would reflect the current situation and offer a conceptual model of IceCSF. The rest of the paper is organized as follows: Section II related work, Section III results, and Section IV conclusions.

Online ISSN 2256-070X https://doi.org/10.17770/etr2021vol2.6620 


\section{RELATED WORK}

Examining the identified scientific articles, the authors conducted an empirical study on the impact of different shopping websites on utilitarian and hedonic values when shopping online. The [2] study confirms that new purchases must be converted into recurring ones for a successful business development strategy. The authors confirmed that the quality $=>$ value $=>$ satisfaction $=>$ loyalty (intention to make a repeat purchase) chain mechanism explains the key to the success of an e-commerce business. This chain mechanism differs significantly from that used by researchers in consumer behavior and marketing literature, who argue that these consumers' loyalty and repurchase intent could be based directly on a higher quality of product/service. The study [2] shows that quality cannot be considered an excellent factor to encourage repeat shopping in an e-commerce environment, as consumers value products and services primarily based on their needs, desires, entertainment, and usefulness. Utilitarian and hedonic values are what lead consumers to intend to repurchase. Besides, the results obtained indicate that the chain mechanism may work slightly differently, in some cases when such demographic factors influence it as consumer income level, gender, age.

The authors of the article [3] believe that too much attention is paid to understanding e-commerce shopping behavior, and too little attention is paid to retail ethics (PCORE model). The obtained results indicated that consumers' perceptions of retail e-commerce ethics consist mainly of 5-factor dimensions - security, privacy, nondeception, performance, reliability, and service recovery. The findings of the study suggest a link between the PCORE model and customer satisfaction. The results also confirm previous research that retail e-commerce ethics can significantly impact customer satisfaction, suggesting that companies with good ethics can build favorable relationships with potential customers, thus enhancing customer satisfaction and trust.

The author of this [4] study has summarized consumers' central perceived values, such as emotional values, quality/performance values, and monetary values, which can directly influence e-commerce consumers' intentions about whether they want to buy a company's products services. On the other hand, this paper [6] presents an adaptive hybrid intelligent computing model (AHICM) to analyze consumer behavior for business development. Trust is an essential factor when looking at it directly in the context of online shopping behavior. In publication [7] emphasizes the sensitivity of individuals to the ratio of payments. The results of the study strongly show how closely trust is linked to consumer behavior as such.

Precious research has been done by authors [8] who have studied whether a deep hybrid learning approach using various customer data can help predict customer repeat purchases and future behavior. The results were surprising; with a deep hybrid machining approach, predicting up to $90 \%$ of consumer behavior concerning repeat purchases is possible. Customer loyalty to the brand was considered a critical underlying factor.
ECT (Expectancy confirmation theory) theory is a general approach to study e-commerce customer satisfaction and behavior research, including product repurchase, further use of the service. The ECT theory's basis states that the customer's behavior to make a repeated purchase or not stop using the service is mainly influenced by the satisfaction with the product or service experienced in the past. The study conducted by the authors has confirmed the theoretical position that satisfaction is the main factor influencing repeat purchases. [10]

In the research [11], the authors have assessed various possible factors influencing customers' repeated purchases in social e-commerce, including word-of-mouth (WOM) intentions. In particular, research has shown that trust and satisfaction influence customer behavior, including the intention to make repeated purchases, but the availability of information quality and a company's reputation are key factors that will affect trust and satisfaction.

The authors' [12] empirical study examines the impact of delivery services on e-commerce customer satisfaction, trust in the company, and the intention to make repeated purchases. Three post-service factors related to customer satisfaction were identified: the possible exchange or return of products and the refund process. The results revealed a relationship between customer satisfaction with the service and the intention to make a repeat purchase.

In turn, paper [13] has looked at the factors influencing customer satisfaction by studying the online shopping experience in general, using data collected by researchers from the 2016 U.K. consumer survey. As a result, the study confirmed that the online shopping experience is influenced by order fulfillment, ease of return, and customer service quality, which significantly affect customer satisfaction. However, customer satisfaction leads the customer to the intention to make a repeat purchase.

The papers [14] aimed to understand the four most important dimensions of e-commerce service quality, which affect customer satisfaction, trust, and behavior. The quality model predicts customer behavior and examines the impact of customer satisfaction on their behavior, such as purchase intent, repeat site visits, trust in the company. The study's analytical results highlighted three factors: quality, namely, site design, security/privacy, performance, which generally affect the quality of e-services. Customer service is not significantly related to the overall quality of eservices. The results show that quality is statistically significantly related to customer behavior, which leads to satisfaction and is ultimately related to making repeated purchases.

The authors [15] have developed the Online Susceptibility Scale (OSS), which assesses the factors that influence consumer decisions when making purchases online; the main reason for defining the scale is that the literature looks at very few factors that directly affect it. This study provides a broad scale of the OSS scale by introducing three factors: online impact of evidence, confirmatory online impact, and online experience. The focus of the study indicates the importance of information when making a purchase decision. Social communication 
and information, and feedback available directly to the consumer play an essential role.

The paper [16] conducted a study offers to get acquainted with and at the same time test a model that examines the quality of relationships as factors between corporate reputation and consumer behavioral intentions. The study's preliminary results showed that overall customer satisfaction is related to company identification, customer commitments, and purchase intentions. Subsequent results confirmed that the corporation's reputation positively impacts customer satisfaction, engagement, and repetition. What significantly influences customers' commitment to repurchase is customer satisfaction.

The main goal of this [17] study was to analyze customer satisfaction in the e-commerce environment. Factors affecting customer satisfaction and the relationship between customer satisfaction and customer spending in ecommerce were identified. The results confirm the customers' satisfaction with the money spent or the desire to make purchases. Further, a link can be observed between if customer satisfaction and spending are positive, a higher level of e-satisfaction emerges, which contributes to the growth of e-commerce. There are direct relationship factors between e-services that affect each other, e-satisfaction and e-loyalty.

The authors [18] believe that the sale of products and their return policy is two signals that can influence consumers' intentions to repurchase online. Also, these signals worked across different market sectors and customer groups, making it a sufficiently important topic for research that could help e-commerce marketers make more profit. Thus, to help online merchants earn more by making effective decisions, a multi-stage hidden Markov model (MS-HMM) is offered, which explores consumer motivation related to customers' intention to make repeated purchases.

The authors of this paper [19] write that e-coupons (electronic coupons) have been one of the foundations of marketing, attracting consumers, and promoting products. To making repurchases, it is necessary to distribute evouchers; delivering them to the right customers is essential. The analysis of consumer preferences for evouchers took into account consumer behavior online and the impact of the resulting data imbalance on low consumer engagement. The authors propose using a two-step hybrid model; the proposed model is applied to actual online consumption data, mainly to properly segment consumers to achieve the desired results and encourage the intention to make repeat purchases.

E-commerce is playing an increasingly important role in consumers' daily lives, mainly due to the crisis caused by COVID-19, the effects of which have changed consumers' attitudes towards online shopping. These rapid developments further reinforce the need to focus on research into consumer behavior. Acquainting with the latest research conducted by various authors, it must be concluded that each emphasizes the vital relationship between consumer behavior, satisfaction, and trust - these are the main key factors that make the customer consider the idea of repurchasing. In turn, the repeated purchase means expanding the circle of regular customers, which is interconnected with gaining and maintaining the customer's trust or loyalty. Upon reaching this stage, e-commerce retailers increase their sales, which facilitates sales. These are the unifying factors for any e-commerce product or service industry.

\section{RESULTS}

The findings are summarized in a conceptual model to identify the factors that affect customer repurchase in e-commerce retail.

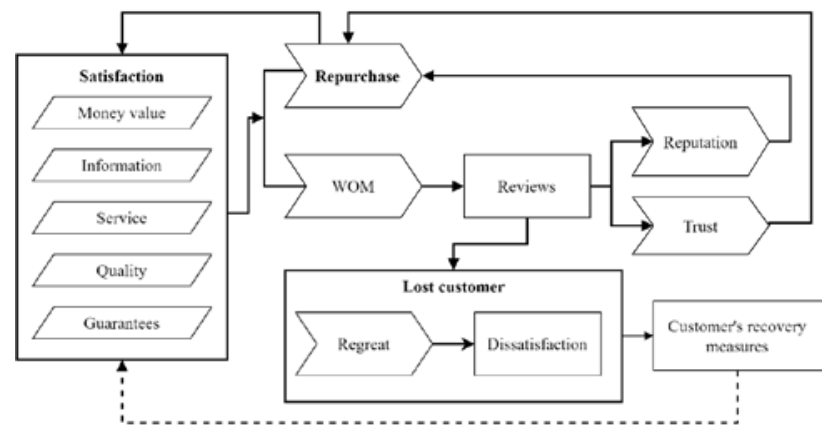

Fig. 1. The factors that affect customer repurchase in e-commerce retail [2-19].

Such factors influence consumer satisfaction as money value, information, service, quality, guarantee. The consumer goes through several stages until he decides to make a purchase, receives it - then he begins to form an idea of the purchased product or service received and the company from which he received it. If the customer is satisfied, they will make a repeat purchase. The customer can express their feedback on the product or service to others; it can be positive and negative. If the feedback is positive, he/she will make repeated purchases himself but will recommend it to others; it will create a good reputation for the company and loyalty to the company. If the customer is dissatisfied, he/she experiences regret about the last purchase or service received. He/she can express his/her dissatisfaction out loud, but he/she can also keep it quiet. In this case, it can be assuming that it is a lost customer or a repurchase will not take place.

By creating successful customer satisfaction, it is needed to know much different data needs to be collected. The next step would be to be aware of how customer satisfaction can be measured with mathematical models and the factors that affect it. Before, the last step would be to predict the possible occurrence or non-occurrence of satisfaction. In the end, obtaining both negative and positive results, perform various activities that would turn from negative results to positive ones and identify positive results to keep repurchases in the future. Combining the problem in a conceptual model that should be developed as a framework for the future. Identification Causes and Effects of Customer Satisfaction Framework (IceCSF) is offered as a solution. 


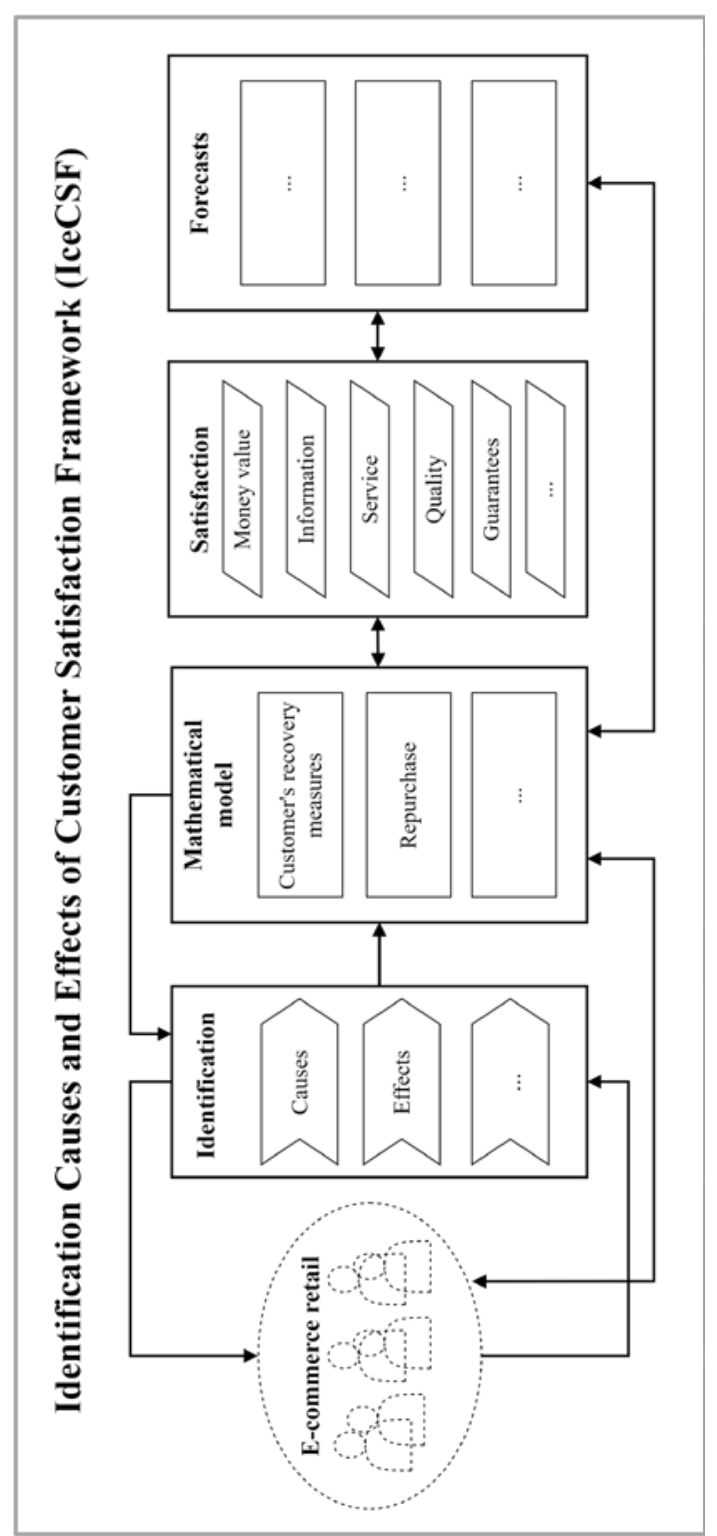

Fig. 2. Conceptual model of Identification Causes and Effects of Customer Satisfaction Framework (IceCSF) in e-commerce retail [Created by the author]

It can be concluded in Fig. 2 that this offer is at the conceptual level, and it is necessary to go into each element in depth.

\section{CONCLUSIONS}

A review of recent critical literature on the factors influencing customer behavior, satisfaction, and repeat purchase intentions in e-commerce in recent years has provided a summary of the main influencing factors. Combining the best results of the research, we developed our conceptual model, which answers the question raised by the research: What factors affect a repurchase? The main factors that affect customer satisfaction are money value, information, service, quality, guarantee. These groups of factors make up the customer's satisfaction with the product or service received. Satisfaction leads to other consumer behavior - if he is satisfied, he will make a repeat purchase and recommend the company to others. By expressing our feedback and opinion, whether it is assessed as positive or negative, the customer builds its reputation, followed by reliability. If the customer's feedback is positive, it will encourage other potential customers to make purchases; thus, the company acquires a new circle of regular customers. Also, if the customer has made several repeated purchases, the importance of loyalty and the loyal customer base's contribution to the company could be studied in this context. On the other hand, if the customer is dissatisfied with his experience, he can also express negative feedback loudly or by holding it to himself. In this case, it can be considered that the customer is dissatisfied, and the possibility that he will make a repeat purchase is negative.

\section{REFERENCES}

[1] Central Statistical Bureau of Latvia, https://www.csb.gov.lv/lv/statistika [Accessed on 05.04.2021]

[2] Changsu K., R. D.-H. (2012). Factors influencing Internet shopping value and customer repurchase intention. Electronic Commerce Research and Applications, 11(4), pp. 374-387. doi:10.1016/j.elerap.2012.04.002.

[3] Elbeltagi, I. A. (2016). E-retailing ethics and its impact on customer satisfaction and repurchase intention: A cultural and commitmenttrust theory perspective. Internet Research, 26(1), pp. 288-310. doi:10.1108/IntR-10-2014-0244

[4] Hsiao-Chi Ling, H.-R. C.-L. (2021). Exploring the factors affecting customers' intention to purchase a smart speaker. Journal of Retailing and Consumer Services, 59. doi:10.1016/j.jretconser.2020.102331

[5] Jen-Ruei Fu, I.-W. L.-K. (2020). Investigating consumers' online social shopping intention: An information processing perspective. International Journal of Information Management, 54. doi:10.1016/j.ijinfomgt.2020.102189

[6] Jia Zhao, F. X. (2021). Consumer behaviour analysis for business development. Aggression and Violent Behavior. doi:10.1016/j.avb.2021.101591

[7] Jian Mou, M. B. (2021). Consumer behavior in social commerce: Results from a meta-analysis. Technological Forecasting and Social Change, 167. doi:10.1016/j.techfore.2021.120734

[8] Jina Kim, H. J. (2021). A deep hybrid learning model for customer repurchase behavior. Journal of Retailing and Consumer Services, 59. doi:10.1016/j.jretconser.2020.102381

[9] Jones, M. A. (2000). Switching barriers and repurchase intentions in services. Journal of Retailing, 76(4), pp. 259-274. doi:10.1016/S0022-4359(00)00024-5

[10] Liao, C. L.-.. (2017). Factors influencing online shoppers' repurchase intentions: The roles of satisfaction and regret. Information and Management, 54(5), pp. 651-668. doi:doi:10.1016/j.im.2016.12.005

[11] Meilatinova, N. (2021). Social commerce: Factors affecting customer repurchase and word-of-mouth intentions. International Journal of Information Management, 57. doi:10.1016/j.ijinfomgt.2020.102300

[12] Muhammad Kashif Javed, M. W. (2020). Effects of online retailer after delivery services on repurchase intention: An empirical analysis of customers' past experience and future confidence with the retailer. Journal of Retailing and Consumer Services, 54. doi:10.1016/j.jretconser.2019.101942

[13] Pham, T. S. (2017). Antecedents and consequences of online customer satisfaction: A holistic process perspective. Technological Forecasting and Social Change. Technological Forecasting and Social Change, 124, pp. 332-342. doi:10.1016/j.techfore.2017.04.003

[14] Rita, P. O. (2019). The impact of e-service quality and customer satisfaction on customer behavior in online shopping. Heliyon, 5(10). doi:10.1016/j.heliyon.2019.e02690 
[15] Seiders, K. V. (2005). Do satisfied customers buy more? examining moderating influences in a retailing context. Journal of Marketing, 69(4), pp. 26-43. doi:10.1509/jmkg.2005.69.4.26

[16] Semila Fernandes, V. V. (2021). Measurement of factors influencing online shopper buying decisions: A scale development and validation. Journal of Retailing and Consumer Services, 59. doi:10.1016/j.jretconser.2020.102394

[17] Su, L., Swanson, S. R., Chinchanachokchai, S., \& Hsu, M. K. (2016). Reputation and intentions: The role of satisfaction, identification, and commitment. 69(9), pp. 3261-3269. doi:10.1016/j.jbusres.2016.02.023
[18] Tahir M. N, G. P. (2017). What factors determine e-satisfaction and consumer spending in e-commerce retailing? Journal of Retailing and Consumer Services, 39, pp. 135-144. doi:10.1016/j.jretconser.2017.07.010.

[19] Xiaolin Li, Y. Z. (2019). A multi-stage hidden Markov model of customer repurchase motivation in online shopping. Decision Support Systems, 129, pp. 72-80. doi:10.1016/j.dss.2019.03.012

[20] Xinxin Ren, J. C. (2021). A two-stage model for forecasting consumers' intention to purchase with e-coupons. Journal of Retailing and Consumer Services, 59 doi:10.1016/j.jretconser.2020.102289 